\title{
Przeciwko cichej akceptacji
}

Sojusz nieczystych sumień. Inteligencja

polska i jej elity na przetomie XX $i$ XXI

wieku

Stanisław Murzański

Kraków 2010, ss. 314.

\author{
„Kto się odwraca od przeszłości, \\ bystrość wzroku zamienia na białą laskę, \\ która niewidomemu pomaga omijać przeszkody, \\ lecz nie wskaże kierunku"
}

Teśli chciałoby się spuentować jednym zdaniem, to należałoby stwierdzić, że przede wszystkim jest to książka „zadawania pytań”. Stanisław Murzański nie boi się ich stawiać. Właściwie w tym twierdzeniu zawiera się istota tej pozycji. Młodego czytelnika pytania mogą wprawić w osłupienie niczym wysłuchiwanie kiedyś Sokratesa. Wynika to z tego, iż dotykają one specyficznego tabu obecnego w życiu społecznym oraz politycznym. Mianowicie, autor zmierza się z kwestią uwikłania „autorytetów”2 w afirmację reżimu totalitarnego w Polsce. Wspomniane „zadawanie pytan” jest jednak podwójnego rodzaju.

S. Murzański potrafi wątpić, zastanawiać się w samym dziele. Pyta i odpowiada, podczas gdy mógłby zostawić czytelnika wyłącznie z remedium na dany problem. S. Murzański wywołuje problem, co wprawia czytelnika w pewne zakłopotanie, gdyż sam musi się chwilę zastanowić, a potem proponuje swoje rozwiązanie.

To pytanie czytelnika o to, co czyta, stanowi drugi poziom zadawania pytań. Nieustannie lekturze towarzyszą pytania, jak chociażby to: „Co ja bym zrobił na ich miejscu?”. Po czym, czytając S. Murzańskiego, bohatera niemal samotnego, który potrafił oprzeć się pokusie, wybrać

${ }^{1}$ S. Murzański, Sojusz nieczystych sumień. Inteligencja polska i jej elity na przetomie XX i XXI wieku,Kraków 2010, s. 145.

${ }^{2}$ Celowo zastosowano cudzysłów, co jest zgodne z nomenklaturą użytą przez S. Murzańskiego. 
życie trudniejsze, można zadać pytanie o sens tego poprzedniego. Biografia autora świadczy bowiem o tym, iż „można było wybrać”. Właśnie o te wybory chodzi.

S. Murzański nie demaskuje jednak kolosa na glinianych nogach, czyli logiki czyjejś, lecz logiki wynikającej z systemu, który ukształtował wizerunek inteligencji polskiej obecny we współczesności. System jako „układ elementów mający określoną strukturę i stanowiący logicznie uporządkowaną całość" został uformowany przez zależności o podłożu ideologicznym, które wyniknęły z wyborów, jakich młodzi ludzie, u progu pełnej dojrzałości dokonywali w okresie stalinizmu i potem.

Ideą książki jest myśl, iż te wybory z młodości, rzutują na przyszłość. Obala ona mit idealistycznego podejścia młodzieży w latach stalinowskich, w których to „budowanie” państwa polskiego jawiło się jako proces nieustannego osiągania sukcesów.

„Byłem przerażony, gdy młody bezpieczniak w trakcie «konwejeru», czyli "przesłuchania» ciągnącego się bez przerwy (funkcjonariusze zmieniali się co kilka godzin) aż do psychicznego bądź fizycznego załamania ofiary, powiedział: «No co, potrafimy nie gorzej niż gestapo?». Było w tym pytaniu coś z dumy zawodowej (...)”3. Autor pyta, jak to się stało, że takie postawy tuż po zakończeniu wojny, zostały wywołane. Jedną z przyczyn upatruje właśnie w działalności młodej rzeszy „intelektualistów”, których działalność należałoby interpretować przez pryzmat skutków, a nie treści. Przytacza w swojej książce jedną z najbardziej znanych książek o zaangażowaniu inteligencji ${ }^{4}$ i rozprawia się z nią właśnie sokratejsko, analizując logikę wypowiedzi jej autorki, która pisze „tam gdzie nazizm głosił apologie przemocy, komunizm odwoływał się do przemocy jako środka realizacji najbardziej szczytnych wartości zachodniej cywilizacji”. Innymi słowy - środek usprawiedliwia czyny. Dalej S. Murzański pyta o to, iż skoro uznajemy w sposób uniwersalny, za Stalinem, że pisarze to „inżynierowie dusz ludzkich", to kim byli intelektualiści w owym czasie? Musieli być konstruktorami rzeczywistości, a jednocześnie ulegali „zasłonom dymnym", rozumianym jako propaganda. Co zatem stanowi rozwiązanie? Ocena ze względu na skutek działania, dlatego że - jak pisze Maria Hirszowicz - to intelektualiści tworzą ogólne idee, które

3 Ibidem, s. 16.

${ }^{4}$ Mowa o M. Hirszowicz, Pułapki zaangażowania. Intelektualiści w stużbie komunizmu, Warszawa 2001.

${ }_{5}$ Za: S. Murzański, Sojusz..., op. cit., s. 19. 
przyjmuje reszta społeczeństwa. Dlatego winni być ludźmi odpowiedzialnymi ${ }^{6}$.

Afirmacja systemu, jakiej dokonywały postacie, które dziś odbierane są w życiu publicznym jako „autorytety” skłania czytelnika do kolejnych refleksji. Takie osobistości jak Tadeusz Mazowiecki, który pisał: „Musimy to poczucie współodpowiedzialności za los socjalistycznej ojczyzny, za nieodwracalność, wielkość, piękno i rozwój jej przemian społecznych - pogłębiać i czynić coraz bardziej dojrzałym”, akceptowały system w latach największego terroru. Przytoczyć także można fragment „rezolucji” Związku Literatów Polskich, którzy pisali o „potępieniu zdrajców ojczyzny, którzy (...) uprawiali - za amerykańskie pieniądze - szpiegostwo i dywersję". Sygnowali to m.in. Wisława Szymborska oraz Sławomir Mrożek ${ }^{9}$. Tego typu świadectw jest w książce S. Murzańskiego więcej. O tyle warto je znać, że stanowią one uzasadnienie idei książki. Skądinąd, za takim rozumieniem cyklu życia, polegającym na tym, iż krok podjęty w młodości skutkuje wyborem kształtu drogi przez resztę życia, przemawia psychologia rozwoju. Wiek 20-25 lat to wiek kształtowania poglądów, osobowości u człowieka. Wystarczy odwołać się chociażby do pojęcia „socjalizacji politycznej” oraz ludzi, których psychologowie nazywają „konsumentami polityki rządu", ale i do tendencji wybierania ideologii, która mogą „przyczynić się do poprawy warunków materialnych”.

Nie jest to wyłącznie książka o wyborach. S. Murzański pokazuje również przyczyny, które sprawiły, iż przełom transformacyjny został dokonany przez określone środowiska przy ograniczeniu roli innych, których psychologia społeczna nazywa „dewiantami” ${ }^{11}$. S. Murzański

${ }^{6}$ Nawiasem mówiąc S. Murzański eksponuje swoisty „komfort” przynależności do inteligencji, która powinna być odpowiedzialna za swoje czyny i słowa ze względu na to oddziaływanie na, ogólnie mówiąc, życie publiczne. Otóż zauważa, że „kiedy jakaś idea okaże się bublem” i „wpędza szaraczków w tarapaty”, to ci ostatni nie mogą domagać się w sądzie zadośćuczynienia za doznane krzywdy. Intelektualista zaś może szaraczka zwymyślać publicznie i... wytoczyć sprawę sądową. „Lepiej być intelektualistą”. Zob.: ibidem, s. 20.

${ }^{7}$ Ibidem, s. 24.

${ }^{8}$ Ibidem, s. 25.

9 Debiutancki tomik poezji noblistki zresztą był utrzymany w konwencji socrealistycznej. Wystarczy wspomnieć frazy, w których Lenina nazywa „Adamem nowego człowieczeństwa”. Zob. Szymborska - Wiersze, http://tytus.tripod.com/szymbo/szymbo. htm, 28.10.2010 r.

${ }^{10}$ Zob. S. Kowalik, Rozwój społeczny, [w:] Psychologia rozwoju człowieka. Rozwój funkcji psychicznych, red. B. Harwas-Napierała, J. Trempała, Warszawa 2002, s. 97-98.

${ }^{11} \mathrm{O}$ samych dewiantach, niezgodności między nimi a resztą grupy przeczytać można 
ujmuje w postaci pewnej ewolucji, która rozpoczyna się od oczywiście młodzieńczych wyborów, uczestnictwa w organizacjach, przez kontakty z lewicąna zachodzie, podziału wewnątrz KOR, rozmów z lewicowym skrzydłem. Trudno w tej recenzji przedstawić wszystkie fakty, dlatego warto sięgnąć do tej książki. Znów czytelnik zadaje sobie pytanie o to, czy kwestia, kto zasiądzie przy „Okrągłym Stole”, nie została rozstrzygnięta w czasach, gdy tzw. „odwilż październikową” traktowano jako powiew wolności. Na to pytanie S. Murzański pomaga odpowiedzieć. Przykład stanowi postać Jacka Kuronia, który w młodości „wywalczył sformułowanie w deklaracji zjazdowej: «ZHP pracuje pod kierownictwem PZPR»"12. J. Kuroń potem już jako opozycjonista rozwijał sieć kontaktów z lewicą na zachodzie. To, iż S. Murzański określa przedstawicieli lewicy jako „towarzyszy”, nie jest przypadkowe. Część tych środowisk tworzyli przecież „spadochroniarze” wysłani przez ZSRR. Któż więc lepiej mógł się porozumieć z nimi, jeśli nie ten, który pisał o socjalizmie jako o „królestwie wolności”? I z kim łatwiej prowadziło się rozmowy - z Antonim Macierewiczem zdumionym składem salonu opozycyjnego pełnego osób ze stalinowską przeszłością czy J. Kuroniem, którego opozycyjność - jak pisze S. Murzański - była zachowawcza? To również świadczy o wieloaspektowości tej pozycji, gdyż dotyka ona wielu problemów, z jakimi borykała się opozycja. Podejmuje również S. Murzański rozważania o celowości formy głównego nurtu opozycji (czyt. lewicowego - przyp. M. B.). Do tych fragmentów również warto sięgnąć. Ponadto wspomina się także o dziś zapomnianych momentach historii lat osiemdziesiątych, jak chociażby o „negocjacjach politycznych”, które były prowadzone za pośrednictwem Służby Bezpieczeństwa właśnie ze środowiskiem J. Kuronia oraz istnieniu drugiego nurtu $^{13}$. Ten ostatni trwał nieustannie w poglądzie, iż zachowawczość, brak projektów zmian to miraż istnienia. „Opozycja, która nie wyobra-

chociażby w: W. Szydło, Grupowe strategie redukowania napięcia jako konsekwencji rozpoznanej niezgodności - zgoda buduje, niezgodę się eliminuje, [w:] Konflikt i porozumienie. Psychologiczne podstawy demokracji deliberatywnej, red. J. Reykowski, Warszawa 2007, s. 153-184.

${ }^{12}$ S. Murzański, Sojusz..., op. cit., s. 43.

${ }^{13}$ „Zdaniem J. Kuronia rozmowy przy «Okrągłym Stole» będą w pewnym sensie «dogadywaniem się» elit. Po obu bowiem stronach istnieją siły antyreformatorskie przeciwne jakiemukolwiek porozumieniu - J. Kuroń przypuszcza, że w obozie opozycji poza porozumieniem pozostaną radykałowie i niepodległościowcy"- czytamy w cytowanym przez S. Murzańskiego dokumencie. Świadczy on o eliminacji „dewiantów”, ale także o powolnym, na razie na zasadzie „przypuszczeń” budowaniu składu stron porozumienia z komunistami. Zob. S. Murzański, Sojusz..., op. cit., s. 121. 
ża sobie przemiany w elitę władzy, nie budzi zaufania do tworzonych przez siebie faktów" - pisał Czesław Bielecki ${ }^{14}$.

To, co kształtowało ludzi w okresie komunizmu, odniosło skutek w latach istnienia III RP. Tak mówi autor książki i trochę również to uzasadnia konstrukcja dzieła. Nieprzypadkowo składa się z dwóch części, dwóch rozległych rozdziałów. Drugi wynikaz pierwszego i jest jego kontynuacją. Pomiędzy nimi zaś jest czas, który Antoni Dudek nazywa „reglamentowaną rewolucją”. Ale nie tylko on wskazuje na to, iż transformacja to kontrakt, który miał zamienić komunistów (hegemona politycznego) w hegemona rynku. O tym pisał również Wiesław Gumuła $^{15}$, ale i inni ${ }^{16}$.

Jest to również książka o pamięci, o zbiorowej odpowiedzialności. Czytelnik zapoznaje się z dywagacjami, czy pamięć to „odpowiedzialność za przeszłość”? Czy istnieje konstrukt zbiorowej odpowiedzialności? Czy jedno i drugie przeplata się ze sobą i dlatego III Rzeczpospolita boryka się z problemami, nie zakończonym etapem transformacji? Bo nie została dokonana sprawiedliwość, jak chociażby w państwach ościennych, a wcześniej w RFN, w której przybrała nazwę „denazyfikacji”? Wiązał się z tym problem numeracji kolejnych form państwa polskiego ${ }^{17}$. Co ciekawe, kolejny raz podkreślić wypada wartość faktograficzną dzieła. Niektórzy, jak marszałek Senatu Andrzej Stelmachowski mówili o „rodzącej się w bólach IV Rzeczypospolitej”18. Autor bulwersuje się wyraźnie i pomstuje: „W takim miejscu! Przy takiej okazji!”19.

Należy również poświęcić część recenzji na uwagi krytyczne. Faktem jest, że S. Murzański nie dopowiada, brakuje uściślenia natury terminologicznej, np. w przypadku „grubej linii” ${ }^{20}$. Język to również problem tej książki. S. Murzański potrafi pisać wprost tak, jak myśli. Pojawiają się tam emocjonalne wyrażenia, np. „generalska szaj-

\footnotetext{
${ }^{14}$ Ibidem, s. 65 .

${ }_{15}$ Zob. W. Gumuła, Teoria osobliwości społecznych. Zaskakująca transformacja $w$ Polsce, Warszawa 2008, s. 236.

${ }^{16}$ Przywołuje się cytat z artykułu Jacka Wasilewskiego i Edmunda Wnuka-Lipińskiego, analizujących strukturę „nowej elity politycznej i przedsiębiorców”. Zob. S. Murzański, Sojusz..., op. cit., s. 163.

${ }^{17}$ S. Murzański PRL nazywa wprost „atrapą sterowaną z Moskwy”. Zob. S. Murzański, Sojusz..., op. cit., s. 130.

${ }^{18}$ Ibidem, s. 130.

${ }_{19}$ Przytacza również źródła, w których nazwa IV Rzeczpospolita była odniesieniem do dzisiejszej III RP.Zob. ibidem, s. 131.

${ }^{20}$ S. Murzański myli „kreskę” z „linią”, co miało znaczenie, jeżeli chodzi o interpretację exposé T. Mazowieckiego, do której przyczyniały się wydarzenia po jego wygłoszeniu, np. palenie akt SB.
} 
ka" (WRON, środowisko gen. Wojciecha Jaruzelskiego). O tyle może to świadczyć na niekorzyść wywodu, że oponenci ideologiczni mogą zarzucić autorowi zacietrzewienie, a przez to brak (próby) podejścia w sposób zobiektywizowany. Oczywiste jest, iż „zaletą tej wady” jest to, że przynajmniej autor nie pozostawia wątpliwości, a więc jest przejrzysty, prawdziwy.

Wydaje się jednak, że postrzeganie książki przez pryzmat ideologiczności byłoby krzywdzące dla niej. Lokowałoby bowiem w określonym miejscu $\mathrm{w}$ politycznym pejzażu zarówno autora, jak i treść. Chodzi raczej o to, aby spojrzeć na nią przez pryzmat prezentacji pewnych faktów, które są objęte społeczną cenzurą, które w demokracji funkcjonująw drugim obiegu (sic!). To jest kolejny głos w dyskusji i kolejna próba pokazania, że biografie „autorytetów” także tych, którzy argumentują często swoje poglądy z pozycji moralisty, nie były moralnie jednoznaczne ${ }^{21}$. A przecież forsuje się wizję pamięci jako procesu funkcjonowania nieustannej alternatywy, pokazywania wielu szczegółów ${ }^{22}$.

I w tym miejscu czytelnik zadaje kolejne pytanie, końcowe - skoro były moralnie dwuznaczne, to na czym oparty jest ich autorytet? $\mathrm{Na}$ prawdzie, na czynach, czy na... braku pamięci? Ponadto, to jest pytanie o to, kogo traktujemy jako autorytet, a zatem również o to, jacy my jesteśmy sami, jeśli etykietujemy zaszczytem ludzi, o których działalności napisał S. Murzański.

\section{Nota O AUTORZE}

Michał Baluch [mbaluch@o2.pl] - student politologii I roku studiów II stopnia na Wydziale Nauk Politycznych i Dziennikarstwa UAM, przedstawiciel Koła Naukowego Psychologii Polityki, autor kilku artykułów naukowych, w których omówione zostały zagadnienia związane

${ }^{21}$ Chociaż S. Murzański ma na ten temat określoną opinię i z pewnością to zdanie potraktowałby jako skrajny eufemizm.

${ }^{22}$ To jest również problem sterowania przeszłością, wykorzystywania w bieżących rozgrywkach politycznych. Ilustrację może stanowić przykład odwoływania się Adama Michnika do przeszłości Lecha Wałęsy, a potem piętnowanie historyków IPN za publikację książki SB a Lech Watęsa. Zob. A. Michnik, Michnik o Grassie: Wałęsa w sforze naganiaczy, „Gazeta Wyborcza”, http://wyborcza.pl/1,75546,3551753.html oraz A. Michnik, Zła przeszłość i psy gończe, czyli odpieprzcie się od Wałęsy, „Gazeta Wyborcza”, http://wyborcza.pl/1,91250,5427362,Zla_przeszlosc_i_psy_goncze_czyli_odpieprzcie_sie.html, 28.10.2010 r. 
m.in. z obecnością stereotypów w języku, kampaniami negatywnymi, buntem w warunkach reżimu demokratycznego i czynnikami ów bunt ograniczającymi, a także z pamięcią zbiorową. 